\title{
Sea Water Intrusion Modeling in Rashid Area of Nile Delta (Egypt) via the Inversion of DC Resistivity Data
}

\author{
E. Tarabees ${ }^{1}$, G. El-Qady ${ }^{2}$ \\ ${ }^{1}$ Geology Department, Faculty of Science, Damanhour University, Damanhour, Egypt \\ ${ }^{2}$ National Research Institute for Astronomy and Geophysics, Helwan, Egypt \\ Email: etarabees@yahoo.com
}

Received 25 January 2016; accepted 2 June 2016; published 6 June 2016

Copyright (C) 2016 by authors and Scientific Research Publishing Inc.

This work is licensed under the Creative Commons Attribution International License (CC BY). http://creativecommons.org/licenses/by/4.0/

(c) (i) Open Access

\section{Abstract}

The current research focuses on the detection of sea water intrusion in Rashid area which is located about $75 \mathrm{~km}$ east to Alexandria, Egypt. For this purpose, geoelectrical survey was carried out using the Schlumberger Vertical Electric Sounding (VES) to identify freshwater thickness, sea water intrusion and estimate subsurface lithology. Seventeen VES stations were measured with current electrode separation $(\mathrm{AB} / 2)$ ranging from $1.5 \mathrm{~m}$ to $100 \mathrm{~m}$. Then, the VES data was interpreted using 1-D and 2-D inversion schemes of DC resistivity data based on least squares method with smoothness constrains. The inverted resistivity distribution at relatively shallow depth shows an important low resistivity zone that probably reflects salt water alteration zone (northern parts). Depth to the freshwater bearing layer reaches its maximum at the south and decreases towards the north. From quantitative interpretation, invasion of salt water started at depth about $10 \mathrm{~m}$ at north in the thickness of freshwater bearing layer ranging from 15 to $25 \mathrm{~m}$, while at depth of about $120 \mathrm{~m}$ all the layers were saturated with salt water.

\section{Keywords}

Nile Delta, Ground Water, 2D-Inversion, Resistivity Sounding, Sea Water Intrusion

\section{Introduction}

Egypt is an arid country, where only 3.4 percent of the area is inhabited. Water is the major constraint to the development of the country. Egypt's main water source is the Nile River, whereas the second water source is groundwater, particularly, in the desert areas. 
The search for new sources of water instead of dependence on the Nile River is very important in this country. The major target of the use of groundwater resources is to decrease population density on the already overcrowded Nile valley by building new settlements and land reclamation in the desert areas adjacent to the Nile valley. As the study area is located near the Mediterranean sea, the seawater intrusion has to be monitored in the aquifers.

The area under investigation is located along the Nile delta, between latitudes $31^{\circ} 12^{\prime}$ to $31^{\circ} 28^{\prime} \mathrm{N}$ and longitudes $30^{\circ} 16^{\prime}$ to $30^{\circ} 32^{\prime} \mathrm{E}$ as shown in Figure 1 . The area is covered by three sedimentary depositional cycles within the delta province ranging from mid-Miocene to Holocene.

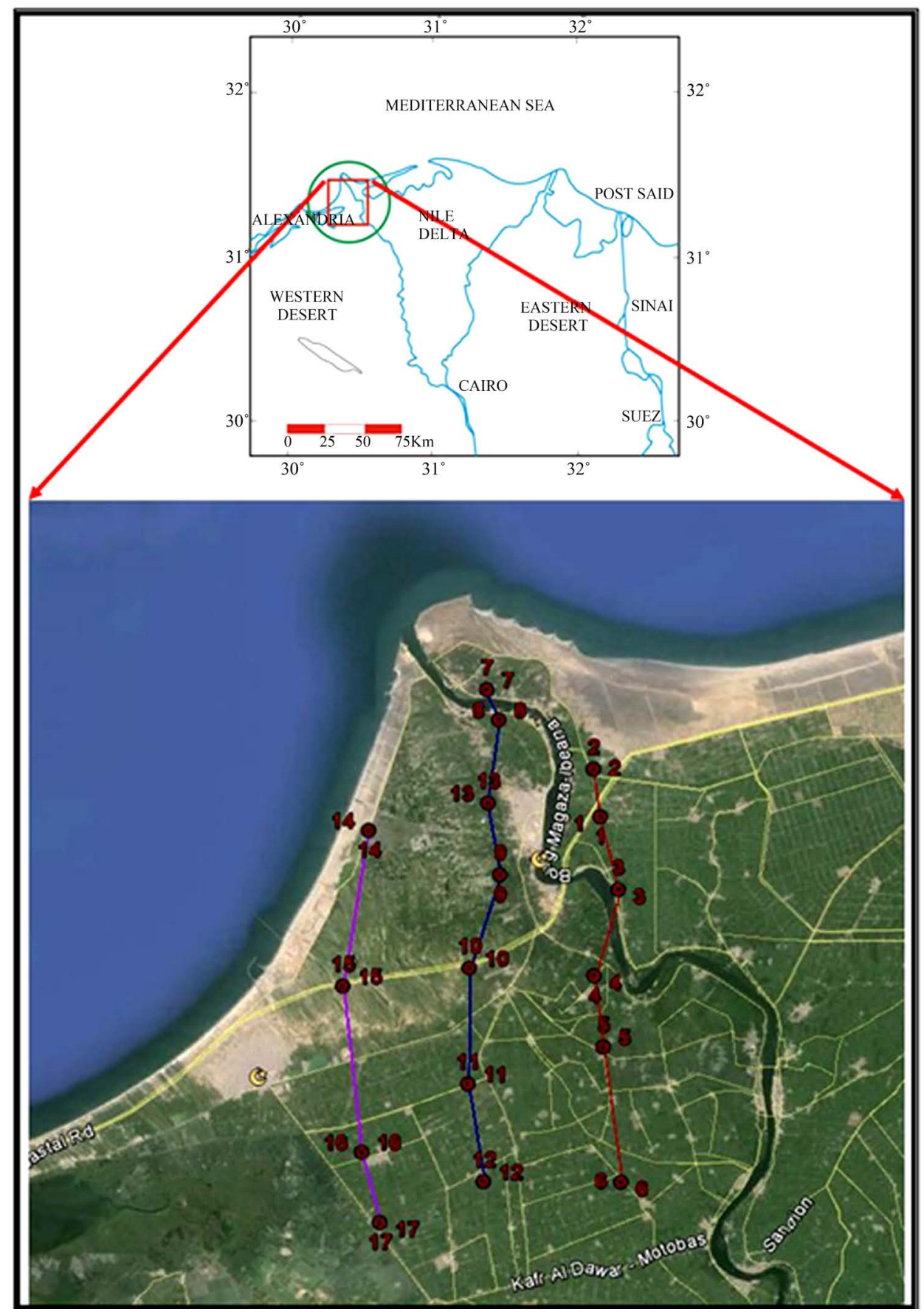

Figure 1. Location map for the study area including the VES locations. 


\section{Geology}

Quaternary deposits constitute the main water bearing formations in Nile delta. These deposits can be classified into Bilqas Formation in the upper parts and MitGhamr formation in the lower part of Figure 2, as in [1]-[3]. The Bilqas formation belongs to the Holocene age. It consists mainly of clay and silt including some sand tracks and sand dunes in the northern coastal area, as well, as some calcareous material at different depths. In the southern part, the Bilqas formation is relatively thin and coarse. Its thickness ranges from 15 to $25 \mathrm{~m}$. which acts as

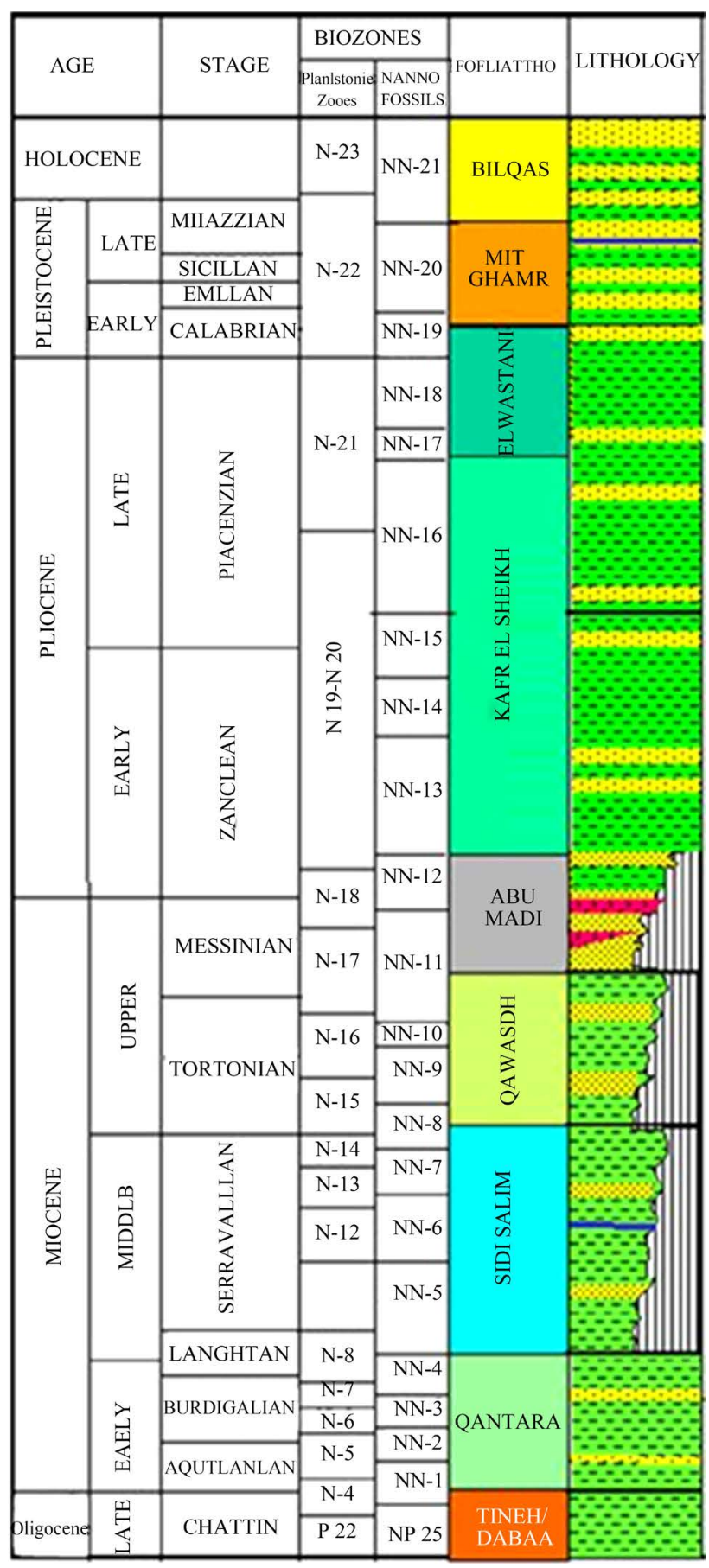

Figure 2. The general geological section of the northern Nile delta as in [6]. 
aquitard for coarser sediments below. In the northern part, it becomes coarser and thick and its thickness reaches more than $50 \mathrm{~m}$, acting as an aquiclude. The Bilqas formation shows distinct lateral variation from sand or silt facies in the south to clay facies in the northern parts, and silty clay facies covering the marginal part of the delta. In the offshore area, clay facies dominate. The change in the facies distribution may be attributed to basin bottom irregularities during deposition and to the load of the old Nile tributaries including their density and energy.

MitGhamr formation of Plio-Pleistocene constitutes the main aquifer of the Nile delta region. MitGhamr formation consists mainly of sand and gravel with occasional thin clay intercalations. The sand and gravel are more common in the southern part. Clay is dominant in the north with occasional discontinuity and intercalation of sand and gravel. Alternating beds of clay and sand with gravel which occur especially, in northern and northeast areas reflect the delta progradation cyclicity sequences. The thickness of these sediments gradually increases towards the north and northeast. The thickness ranges between 100 and $400 \mathrm{~m}$ in the south and from 500 to 700 $\mathrm{m}$ in the middle, while reaches a maximum value of exceeding $900 \mathrm{~m}$ in the north.

The Nile delta aquifer system is considered to be a leaky aquifer in the southern and middle parts and a free aquifer in the western and eastern borders, where the thickness of the top Holocene deposits reaches its minimum value. In the northern part, the top Holocene deposits strongly retard upward discharge from the PlioPleistotcene aquifer. Thick lagoonal impervious clay in the northern part forms an impermeable barrier that retards the fresh Nile water flow to the sea or intrusion of the salt water inland. Other semi-impermeable barriers are the buried channels which are filled with silty clay and clay deposits that impede lateral ground water movement. Between these buried barriers, highly permeable deposits act as natural channels of fresh ground water flow or intrusion of salt water inland as in [4] [5].

\section{Hydrogeophysical Application and Data Interpretation}

Geophysics, specifically, geoelectrical surveys, either in the form of Vertical Electrical Soundings (VES) or horizontal profiling, are often used to search for groundwater in both porous and fissured media as in [7]-[10]. In clean sands and gravels, which have high porosities, constitute good aquifers when saturated with fresh water. They can be easily differentiated from the lower-resistivity impermeable clays and marls, and also from high resistivity bedrocks, as in [11]. Accordingly, the general purpose of this work is to locate the groundwater occurrences in the study area and to investigate the presence of sea water intrusion using the available geophysical data as in [12]-[14]. Therefore, VES were carried out at 17 locations to evaluate the extension of the aquifer and the geological structures that affect the groundwater occurrences. The geoelectrical resistivity measurements in this study were carried out using the Schlumberger array with maximum current electrode spacing (AB) of 100 $\mathrm{m}$ (Figure 1). The measured VES data are subjected to both qualitative and quantitative interpretation.

\subsection{Interpretation}

The VES sounding curves have been analyzed (Figure 3) to show distribution of different curve types in the study area. The distribution of the curve types indicates that no uniform dominated in all the study area, especially, the northern part. This, in turn, reflects the lithology heterogeneity in the area in both vertical and horizontal direction. According to curve type, the first part reflects the moisture content of the soil, where the resistivity value is low. The surface soil is followed by a layer of relatively higher resistivity that may reflect the unsaturated zone. The last part reflects the lower resistivity layer that decreases in resistivity with increasing depth. This layer represents the saturated zone and water salinity.

ISO apparent resistivity contour maps were drawn for selected current electrode separation $\mathrm{AB} / 2=2.5,6,12$, 25, 30, $40 \mathrm{~m}$. Those electrodes separation are the intervals that reflect variations in apparent resistivity values at different depths. Example of these maps is portrayed in Figure 4.

With increasing depth, the rock unit is wet, sandy clay. The resistivity values are high in the middle of the study area and near the Rashid Nile valley mouth. This may be due to the infiltration from the fresh water of the Nile River. The resistivity values in southern part are very low, less than 5 ohms/meter, and this may reflect the presence of saline water. The western part of the study area which represents the coastal area far from Nile River has low resistivity values which are indicative of sea water intrusion.

With increasing the depth, the rock unit also sandy clay saturated with the saline water and this is clear where the resistivity data became very small this reflect the sea water intrusion effect and reflect the coastal saline aquifer. 


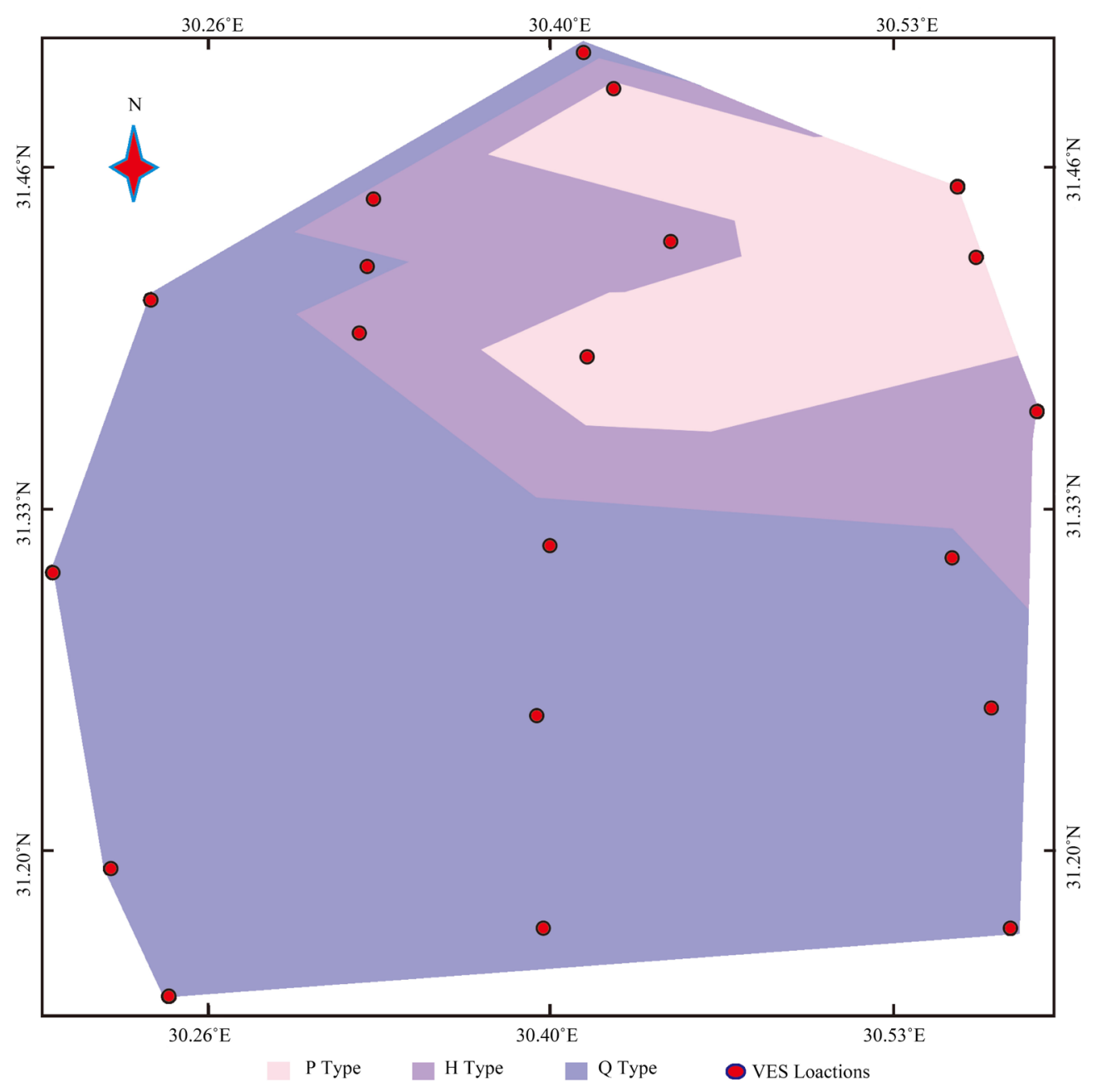

Figure 3. Curves type isopach map.

\subsection{1-D Modeling}

The IX-1D software [15] was used for forward modeling calculations of all VES sounding to get 1-D model. Using the obtained results, the investigated subsurface sequence can be classified into three successive geoelectric zones of different resistivity ranges, thickness and depths. The electrical resistivity of rocks depends on many factors such as lithology, porosity, and saturation degree and groundwater salinity. Forward inversion gives good matching with field data to predict depth to water table and water type. Since there are no general guidelines for interpreting lithology of the contrasting resistivity layers, each area has its own conditions as in [16]. This means that interpretation must be based on local databases that include information on lithology and hydrogeology of the investigated intervals. The investigations are carried out at the following locations:

\section{Group A: VES stations located beside Nile Valley}

Examples of these VES are VES No. 1 and 7 (Figure 5). Investigating the results of modeling, it is evident that the depth of the first geoelectrical layer ranges from 1 to $3 \mathrm{~m}$ with resistivity value from 10 to $100 \mathrm{ohm}$.m. This layer is loose sand, and hence showsrelatively high resistivity value. The second geoelectrical layer has depth ranging from 4 to $6 \mathrm{~m}$ with resistivity value 2 to $70 \mathrm{ohm}$. $\mathrm{m}$. This layer representswet sandy clay with moderate resistivity affected by the river Nile infiltration. The third geoelectrical layer is 6 to more than $100 \mathrm{~m}$ thick with resistivity value in the range 0.6 to $0.8 \mathrm{ohm}$. $\mathrm{m}$ and this layer is sandyclay fully saturated with saline sea water.

Group B: VES station located beside Mediterranean Sea

Investigations show that the first layer has depth of 1 to $2.5 \mathrm{~m}$ with resistivity value 0.6 to $1 \mathrm{ohm}$. $\mathrm{m}$. This is 
(a)

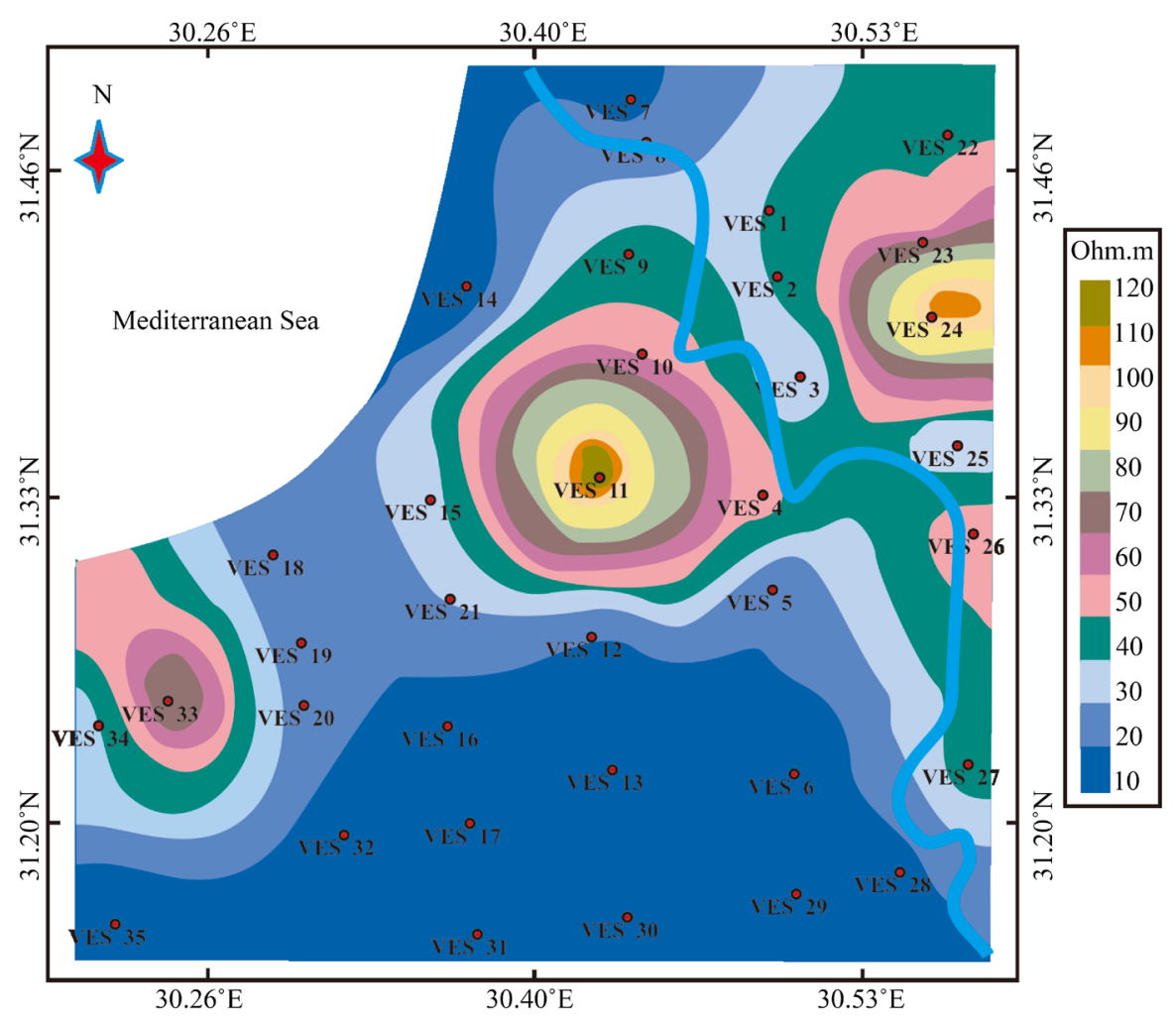

(b)

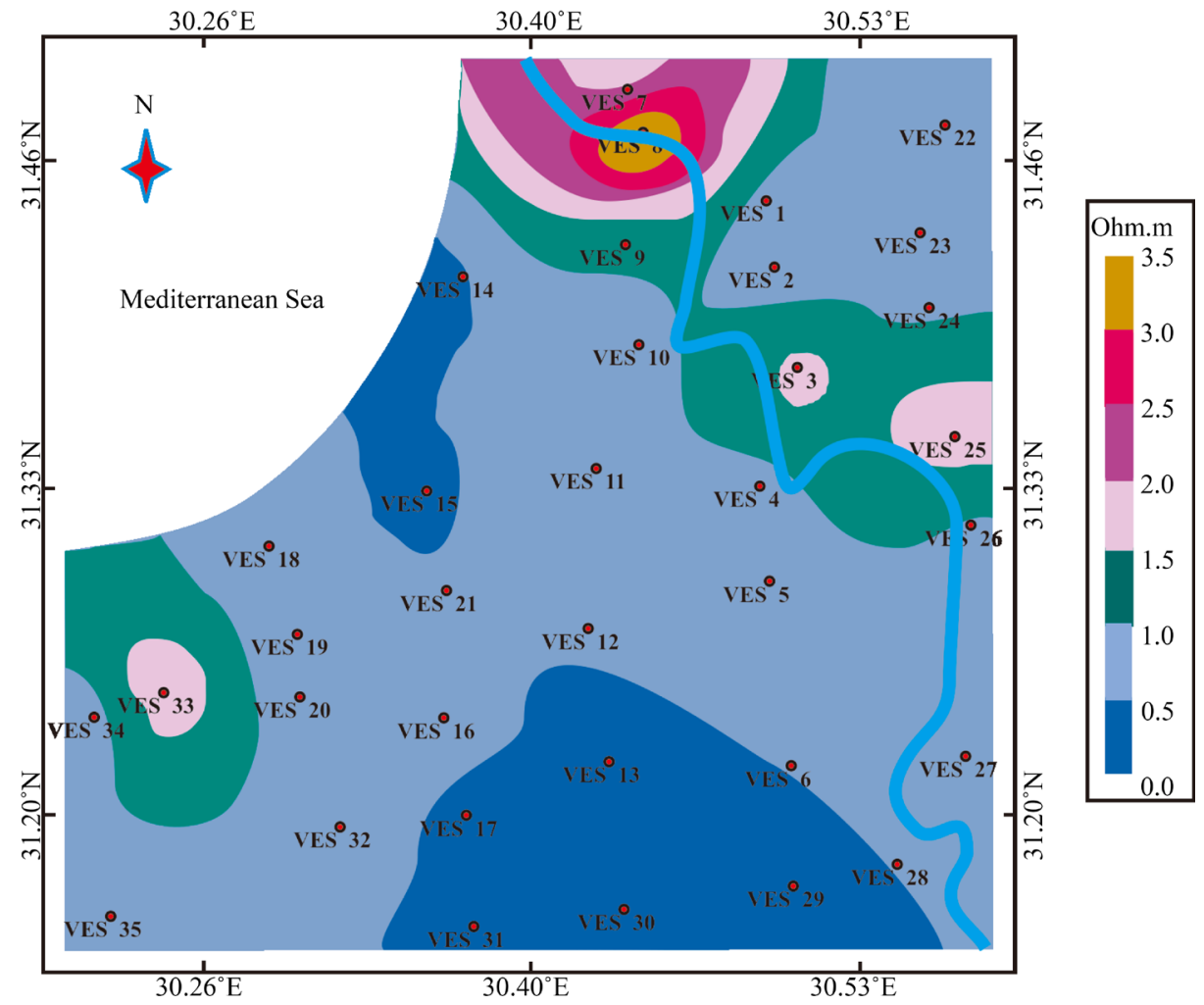

Figure 4. ISO apparent resistivity contour maps at (a) $\mathrm{AB} / 2=2.5 \mathrm{~m}$, (b) $\mathrm{AB} / 2=40 \mathrm{~m}$. 
(a)
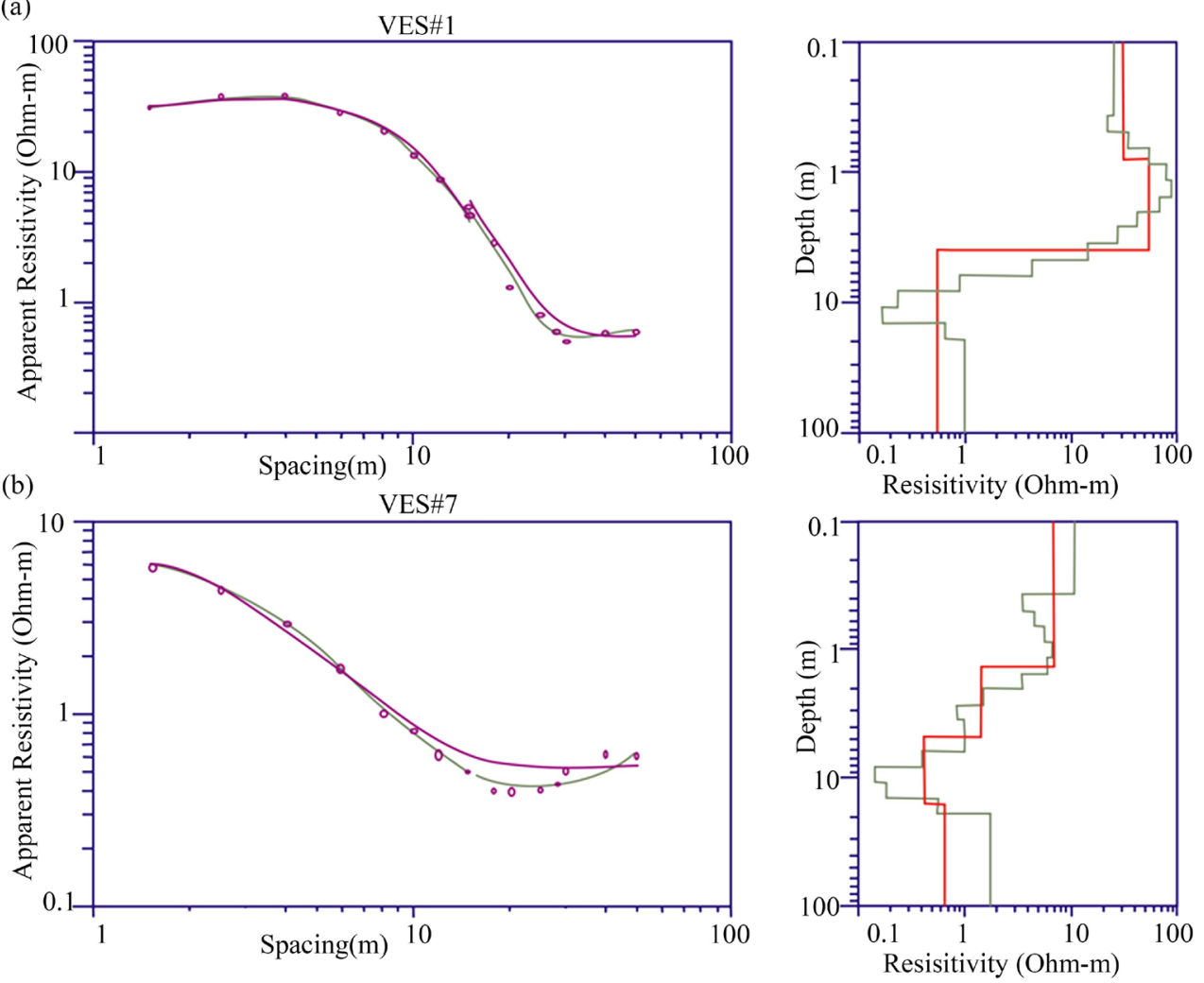

Figure 5. VES stations No. 1and 7 lying beside Nile river.

loose sand sometimes containing salt. The second layer has depth 9 to $11 \mathrm{~m}$ with resistivity 0.2 to $0.3 \mathrm{ohm}$. m. with sandy clay fully saturated with sea water. The third layer has a depth range of 12 to more than $100 \mathrm{~m}$ with resistivity 0.9 to $3.5 \mathrm{ohm}$. This is sandy clay, also saturated with saline sea water in Figure 6.

\subsection{Two Dimensional Inversion of VES Data}

In this section, a 2-D inversion for the same data is presented using Uchida's algorithm as in [17]. This algorithm is based on the ABIC (Akaike Bayesian Information Criterion) to converge to optimum smoothness using finite element. The algorithm considers a 2D-earth model, whose resistivity varies along the $\mathrm{x}$ and $\mathrm{z}$ axes while it does not change along the y axis. For the least squares inversion with smoothness regularization, we seek a model that minimizes both the data misfit and model roughness. From a statistical point of view, ABIC works as an index to determine the maximum likelihood of the 2D-earth model. That means, a smaller ABIC indicates a larger likelihood and higher entropy, hence gives a best-fit model.

According to the results obtained through the inversion process, the 2-D geoelectrical cross sections are constructed for each profile. The cross section represents the model of iteration that minimizes ABIC and gets convergence. Figure 7 shows the 2-D cross section of the inverted model after the forth iteration for line1. The initial model is assumed to be a $30 \mathrm{ohm}$. m homogeneous earth, and the topography is incorporated into the modeling. The number of the observed data used for the inversion is 196, while the number of resistivity blocks is 117.

Results of the interpretation show that, the top dry zone consists of geoelectrical resistivities with more than 6 Ohm. $\mathrm{m}$ at all the VES stations. The water bearing zone consists of two geoelectrical layers according to the resistivities variations. The resistivity of these layers decreases with depth. The upper layer has a resistivity range from 1 to $6 \mathrm{Ohm}$. m. This layer is wet sandy clay partially affected by the sea water intrusion at VES No. 3 and 4.Those two VES locations are beside the Nile valley and are affected by the Nile water intrusion. The lower layer has a resistivity range of $5.2 \mathrm{Ohm} . \mathrm{m}$ to $6.8 \mathrm{Ohm}$. $\mathrm{m}$. The second layer has a large thickness ranging from $52.2 \mathrm{~m}$ to more than $100 \mathrm{~m}$. where the thickness increases toward the south. 

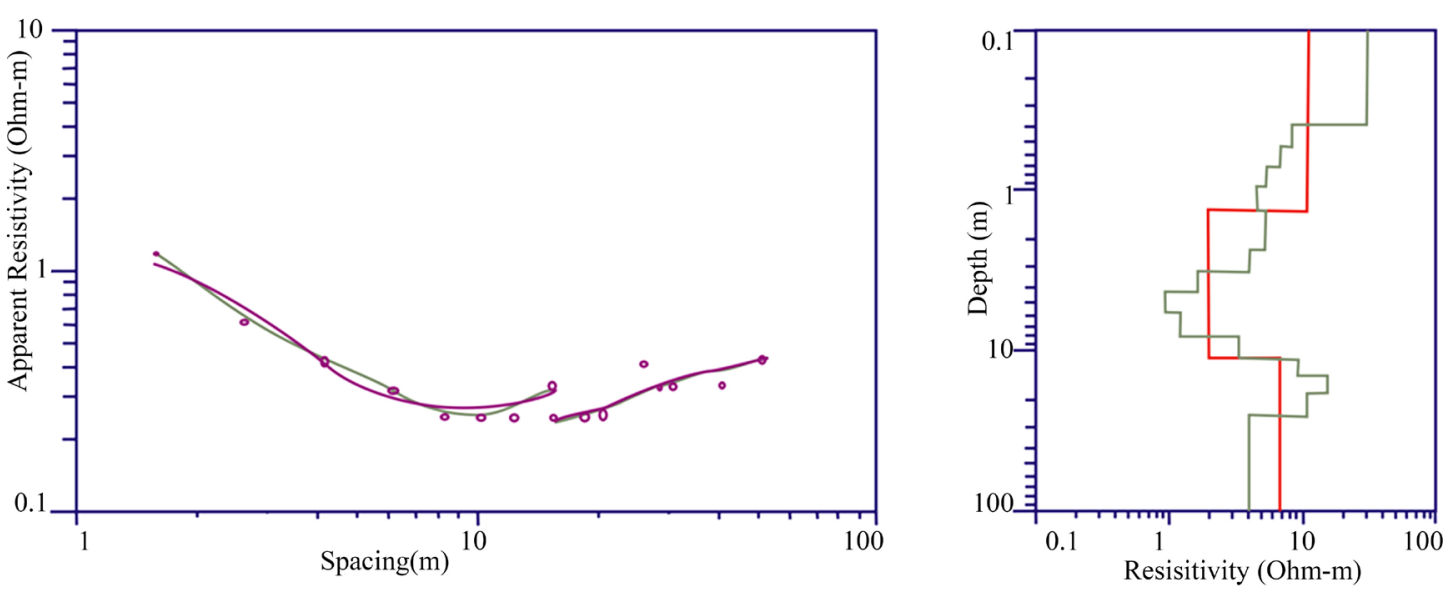

Figure 6. VES stations 17 laying beside Mediterranean sea coast.

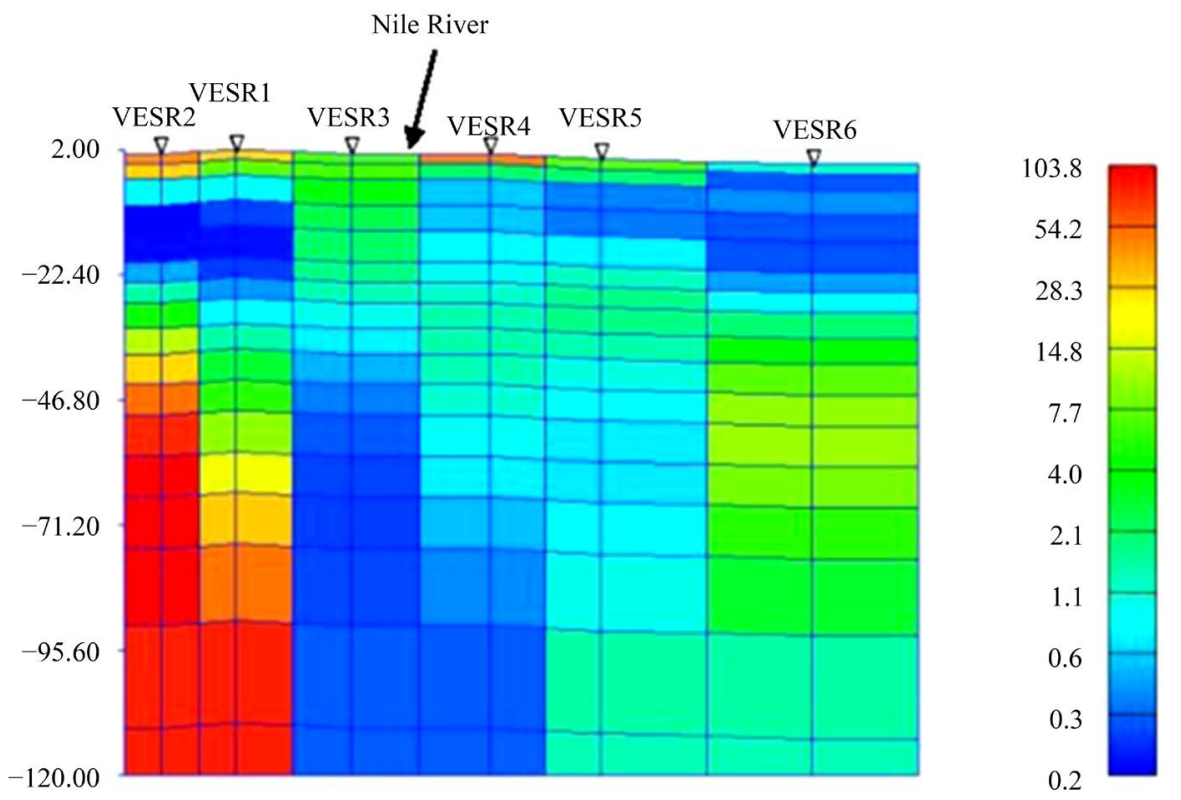

Figure 7. The geoelectrical cross section along profile 1 that resulted from 2-D interpretations.

Investigation of the inversion results from cross section No.2 (Figure 8) show that, the top dry zone consists of high geoelectrical resistivities at all the VES stations. The water bearing zone consists of two geoelectrical layers according to the resistivities variations. The resistivity of these layers decreases with depth. The upper layer has a resistivity range from 1 to $6 \mathrm{Ohm}$. $\mathrm{m}$ and this layer is wet sandy clay partially affected by the sea water intrusion at VES stations No. 7 and 8. Those two VESes are located beside Nile valley and are affected by the Nile valley intrusion. The lower layer is greatly affected by the intrusion of the sea water.

As for the profile No 3, it is located beside the sea coast and very far from the effect of the Nile valley infiltration. So this shows very low resistivity values and represents the coastal aquifer filled with saline water Figure 9.

\section{Conclusions}

The present work is aimed at delineating and elucidating the ground water aquifer at Rashid area, Egypt. To achieve this purpose, ABIC least squares 1-D and 2-D inversion of Schlumberger resistivity soundings measured are applied at the study area. As the inversion procedure can reduce the misfit through iteration, the 2-D calculated response was highly correlated with the observed data (1-D data). The resulting 2-D cross section is correlated with the 1-D inversion. However, the 2-D cross section elaborates the geologic structures, which matches 


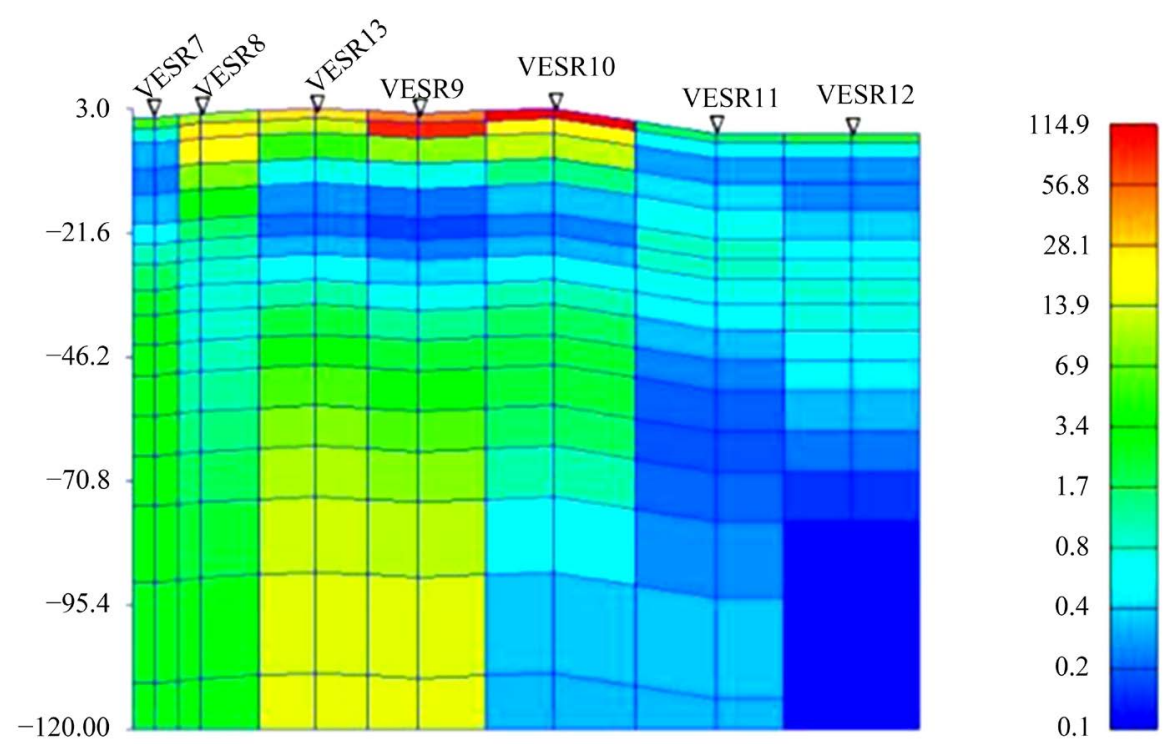

Figure 8. The geoelectrical cross section along profile 2 that resulted from 2-D interpretations.

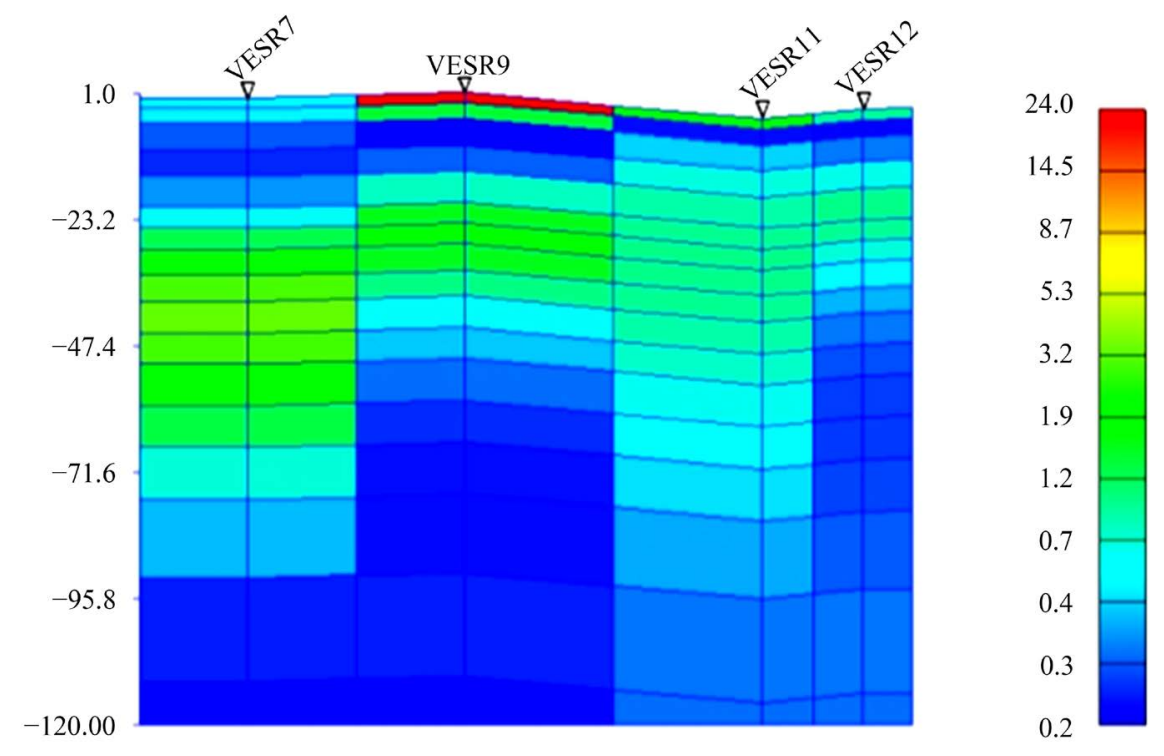

Figure 9. The geoelectrical cross section along profile 3 that resulted from 2-D interpretations.

previously published geologic results.

All stations located beside the sea coast and very far from the effect of the Nile valley infiltration show very low resistivity values and represent the coastal aquifer filled with saline water. The stations located beside Nile valley and far from the sea show relatively high resistivity values. The resistivity values decrease by depth indicating sea water intrusion. The lower layer is greatly affected by the sea water intrusion even far from sea coast.

\section{References}

[1] Said, R. (1981) The Geological Evaluation of the River Nile. Springer Verlag, New York, 151 p. http://dx.doi.org/10.1007/978-1-4612-5841-4

[2] Stanley, D.J. and Warne, A.G. (1993) Nile Delta, Recent Geological Evolution and Human Impact. Science, 260, 628-634. http://dx.doi.org/10.1126/science.260.5108.628 
[3] Stanley, D.J. and Warne, A.G. (1993) Sea Level and Initiation of Predynastic Culture in the Nile Delta. Nature, 363, 435-438. http://dx.doi.org/10.1038/363435a0

[4] Ebraheem, A.M., Sensosy, M.M. and Dahab, K.A. (1997) Geoelectrical and Hydrogeochemical Studies for Delineating Ground-Water Contamination due to Salt-Water Intrusion in the Northern Part of the Nile Delta, Egypt. Groundwater, 35, 216-222. http://dx.doi.org/10.1111/j.1745-6584.1997.tb00077.x

[5] Diab, M.Sh. (1982) Groundwater Pollution in the Quaternary Aquifer under the Nile Delta, Egypt. Journal of Geophysics, Special Volume Part 2, 135-144.

[6] Schlumberger (1984) Well Evaluation Conference, Egypt. Schlumberger Middle East Surface.

[7] Barker, R., (1980) Application of Geophysics in Ground Water Investigations. Water Serv., 84, 489-492.

[8] Van Overmeeren, R. (1989) Aquifer Boundaries Explored by Geoelectrical Measurements in the Coastal Plain of Yemen: A Case of Equivalence. Geophysics, 54, 38-48. http://dx.doi.org/10.1190/1.1442575

[9] Burger, H.R. (1992) Exploration Geophysics of the Shallow Subsurface. Prentice Hall, Inc., Upper Saddle River, 6695.

[10] Loke, M.H., Chambers, J.E., Rucker, D.F., Kuras, O. and Wilkinson, P.B. (2013) Recent Developments in the DirectCurrent Geoelectrical Imaging Method. Journal of Applied Geophysics, 95, 135-156. http://dx.doi.org/10.1016/j.jappgeo.2013.02.017

[11] Bernard, J. and Valla, P. (1991) Ground Water Exploration in Fissured Media with Electrical and VLF Methods. Geoexploration, 27, 81-91. http://dx.doi.org/10.1016/0016-7142(91)90016-6

[12] Lee, J.Y. and Song, S.H. (2007) Evaluation of Groundwater Quality in Coastal Areas: Implications for Sustainable Agriculture. Environmental Geology, 52, 1231-1242. http://dx.doi.org/10.1007/s00254-006-0560-2

[13] Abdul Nassir, S.S., Loke, M.H., Lee, C.Y. and Nawawi, M.N.M. (2000) Salt-Water Intrusion Mapping by Geoelectrical Imaging Surveys. Geophysical Prospecting, 48, 647-661. http://dx.doi.org/10.1046/j.1365-2478.2000.00209.x

[14] Nowroozi, A.A., Horrocks, S.B. and Henderson, P. (1999) Saltwater Intrusion into the Freshwater Aquifer in the Eastern Shore of Virginia: A Reconnaissance Electrical Resistivity Survey. Journal of Applied Geophysics, 42, 1-22. http://dx.doi.org/10.1016/S0926-9851(99)00004-X

[15] Interpex Limited (2008) IX1D v2 Instruction Manual. 67 p.

[16] El-Qady, G., Shaaban, H., El-Said, A., Ghazala, H. and El-Shahat, A. (2011) Tracing of the Defunct Canopic Nile Branch Using Geoelectrical Resistivity Data around Itay El-Baroud Area, Nile Delta, Egypt. Journal of Geophysics and Engineering, 8, 83-91. http://dx.doi.org/10.1088/1742-2132/8/1/010

[17] El-Qady, G., Sakamoto, C. and Ushijima, K. (1999) 2-D Inversion of VES Data at Saqqara Archaeological Area, Egypt. Earth Planets and Space, 51, 1091-1098. http://dx.doi.org/10.1186/BF03351583 